Çukurova Üniversitesi Mühendislik Mimarlık Fakültesi Dergisi, 30(2), 201-215 ss., Aralık 2015

Çukurova University Journal of the Faculty of Engineering and Architecture, 30(2), pp. 201-215, December 2015

\title{
Kuyu Duraylıı̆̆ının Analitik ve Sayısal Yöntemler ile Karşılaştırmalı Bir İncelemesi
}

\author{
Melih GENIŞ ${ }^{* 1}$, Dinçer ACUN ${ }^{2}$ \\ ${ }^{1}$ Bülent Ecevit Üniversitesi, Mühendislik Fakültesi, Maden Mühendisliği Bölümü, Zonguldak \\ ${ }^{2}$ Türkiye Taşkömürü Kurumu, Üzülmez Müessese Müdürlüğü, Zonguldak
}

Geliş tarihi: 04.11.2015

Kabul tarihi: 25.12 .2015

\section{Özet}

Bu çalışmada, kuyu duraylılığın değerlendirilmesi için analitik ve sayısal gerilme çözümlemesi yöntemlerinden faydalanılmıştır. Analitik çözümlerde konverjans sınırlama yöntemi, sayısal çözümlemelerde ise sonlu elemanlar yöntemi kullanılmıştır. Tahkimatlı kuyunun sayısal çözümlemesinde kullanılan yük dağılımı oranları söz konusu yöntemlerden elde edilen sonuçların karşılaştırılmasıyla bulunmuştur. Tahkimatlı açıklıkların modellenmesinde kullanılan yük dağılımı oranları sırasıyla birinci aşamada \%70-75, ikinci aşamada \%25-30 arasında olduğu belirlenmiştir. İncelenen durumlar için kuyunun beton kaplamasının duraylı olduğu sonucuna ulaşılmıştır. Son olarak, tahkimatlı açıklıkların modellenmesinde göz önünde bulundurulan bazı önemli hususlar sunulmaktadır.

Anahtar Kelimeler: Kuyu, Duraylılık, Yenilme, Arazi reaksiyon eğrisi, Tahkimat karakteristik eğrisi

\section{A Comparative Study of Shaft Stability by Analytical and Numerical Methods}

\begin{abstract}
In this study, analytical and numerical stress analyses (methods) were utilized to evaluate the shaft stability. Convergence confinement method and finite element method were used during the analytical and numerical analyses, respectively. Load split ratios used in the numerical solution for the supported shaft were also obtained by comparison of results of the above mentioned methods. It was determined that load split ratios employed for supported openings were $70-75 \%$ in the first stage and $25-30 \%$ in the second stage, respectively. It was concluded that concrete support of shaft is stable for considered conditions. Finally, some important considerations on the modelling of supported openings are presented.
\end{abstract}

Keywords: Shaft, Stability, Failure, Ground reaction curve, Support characteristic curve

\footnotetext{
* Yazışmaların yapılacağı yazar: Melih GENiş, Bülent Ecevit Üniversitesi, Maden Müh. Bölümü, Zonguldak,genis@beun.edu.tr
} 


\section{GíRiş}

Günümüzde maden, inşaat mühendisliği çalışmaları içinde yeraltı açıklıklarının tasarımı, kaya mekaniği disiplinin en önemli konularından birini oluşturmaktadır. Yeraltı açıklıkları, işlevleriyle uyumlu bir duraylığı kendilerinden beklenen hizmet süreleri boyunca gösterebilmelidir [1]. Özellikle uzun süreli hizmet vermesi beklenen ana maden açıklıkları (kuyu, galeri gibi), ulaştırma tünelleri, baraj yapıları tünellerinin kısa ve uzun süreli duraylılık performanslarının doğru tahmin edilmesi, tasarım başarısının temel unsurunu oluşturmaktadır. Bu kapsamda, proje öncesinde yeraltı yapılarının oluşturulacağı kaya malzemesi ve kütlesinin jeomekanik özelliklerinin, birincil gerilme durumunun doğru bir şekilde belirlenmesi büyük önem taşımaktadır. Bununla birlikte duraylık performanslarının tahmininde kullanılabilecek uygun görgül (ampirik), analitik ve sayısal çözümlemelerin problemlere uygulanabilmesi de diğer önemli bir unsurdur.

Bu çalışmada, Amasra-Bartın'da özel sektör tarafından yürütülen Amasra B taşkömürü üretim projesi kapsamında açılan üç kuyudan biri olan Tarlaağzı üretim kuyusu incelenmiştir. Kuyu duraylılığın değerlendirilmesi için analitik ve sayısal gerilme çözümlemesi yöntemleri kullanılarak elde edilen sonuçlar karşılaştırılmıştır. Sonuç olarak tahkimatlı açıklıkların duraylılık değerlendirilmesi amacıyla kullanılan sayısal çözümlemelerde bazı dikkat edilmesi gereken hususlar vurgulanmıştır.

\section{2. ÇÖZÜMLEME YÖNTEMLERİ}

Çalışmada kullanılan analitik çözümleme ve sayısal çözümleme yöntemi alt başlıklarda incelenmiştir.

\subsection{Analitik Çözümleme}

Analitik çözümleme yöntemi olarak "konverjans sınırlama yöntemi (convergence-confinement method)" kullanılmıştır [2]. Arazi ve tahkimat etkileşim analizi için kullanılan basitleştirilmiş olan bu yöntem aslında yatay açıklıklar (tünel) için geliştirilmiş olsa da bu çalışmada dikey açıklıklar (kuyu) için uygulanmıştır. Konverjans sınırlama yöntemi tünel veya kuyu arını gerisinde yapılacak tahkimata etkiyecek izin verilen yükleri tahmin eden bir yöntem olarak tanımlanmaktadır. Kazı aynasında hemen kurulan tahkimat arın çevresinde oluşan tüm yükleri taşımayacaktır. Kazı çevresinde oluşan yüklerin bir kısmı kazılmamış kaya kütlesi tarafından taşınacaktır. Tahkimatın kurulması ve arın ilerlemesinden sonra arın etkisi azalacaktır. Arın tarafindan taşınan yükün bir bölümü tahkimat tarafından taşınacaktır. Tahkimat tarafindan taşınan bu yük tahkimat tasarım yükü olacaktır [2].

Yöntem hidrostatik birincil gerilme altında $\left(P_{o}\right)$ açılan dairesel kesitli bir tünel için geçerlidir. $\mathrm{Bu}$ yöntem kuyu arını çevresinde uygulanmıştır. Problemin basitleştirilmesi içinde açıklık çevresinde oluşan bütün deformasyonların açıklığın uzun eksenine dik düzlem içinde oluştuğu yani düzlem birim şekil değiştirme durumu olduğu varsayılmaktadır. Kaya kütlesinin dayanımı, Hoek-Brown (H-B) yenilme ölçütü ile tanımlanmıştır. Yöntemin uygulanmasında arazi reaksiyon eğrisi ve tahkimat karakteristiklerinin belirlenmesi başlıca unsurları oluşturmaktadır.

\subsubsection{Arazi Reaksiyon Eğrisinin Oluşturulması}

Arazi reaksiyon eğrisi (ground reaction curve, GRC), düzenli içsel basınca (tahkimat basıncı) $\left(p_{i}\right)$ sahip dairesel açıklığın elasto-plastik çözümlemesi ile elde edilmektedir. Tipik bir GRC'de verilen "E" noktası ile tanımlanan kritik içsel basınç $\left(p_{i}^{c r}\right)$, kaya kütlesinin elastik davranıştan elasto-plastik davranışa geçiş yaptığı arazi gerilmesini veya tahkimat basıncını tanımlamaktadır. Diğer bir ifade ile $p_{i} \geq p_{i}^{c r}$ olduğunda kaya kütlesi elastik davranış göstermekte; $p_{i}<p_{i}^{c r}$ olduğunda ise kaya kütlesi elasto-plastik davranış göstererek açıklık çevresinde $R_{p}$ yarıçapında bir yenilme bölgesi oluşmaktadır (Şekil 1). Kritik içsel basınç aşağıdaki eşitlik ile bulunabilir:

$p_{i}^{c r}=\left[P_{i}^{c \mathrm{r}}-\frac{s}{m_{b}^{2}}\right] \mathrm{m}_{\mathrm{b}} \sigma_{\mathrm{ci}}$ 


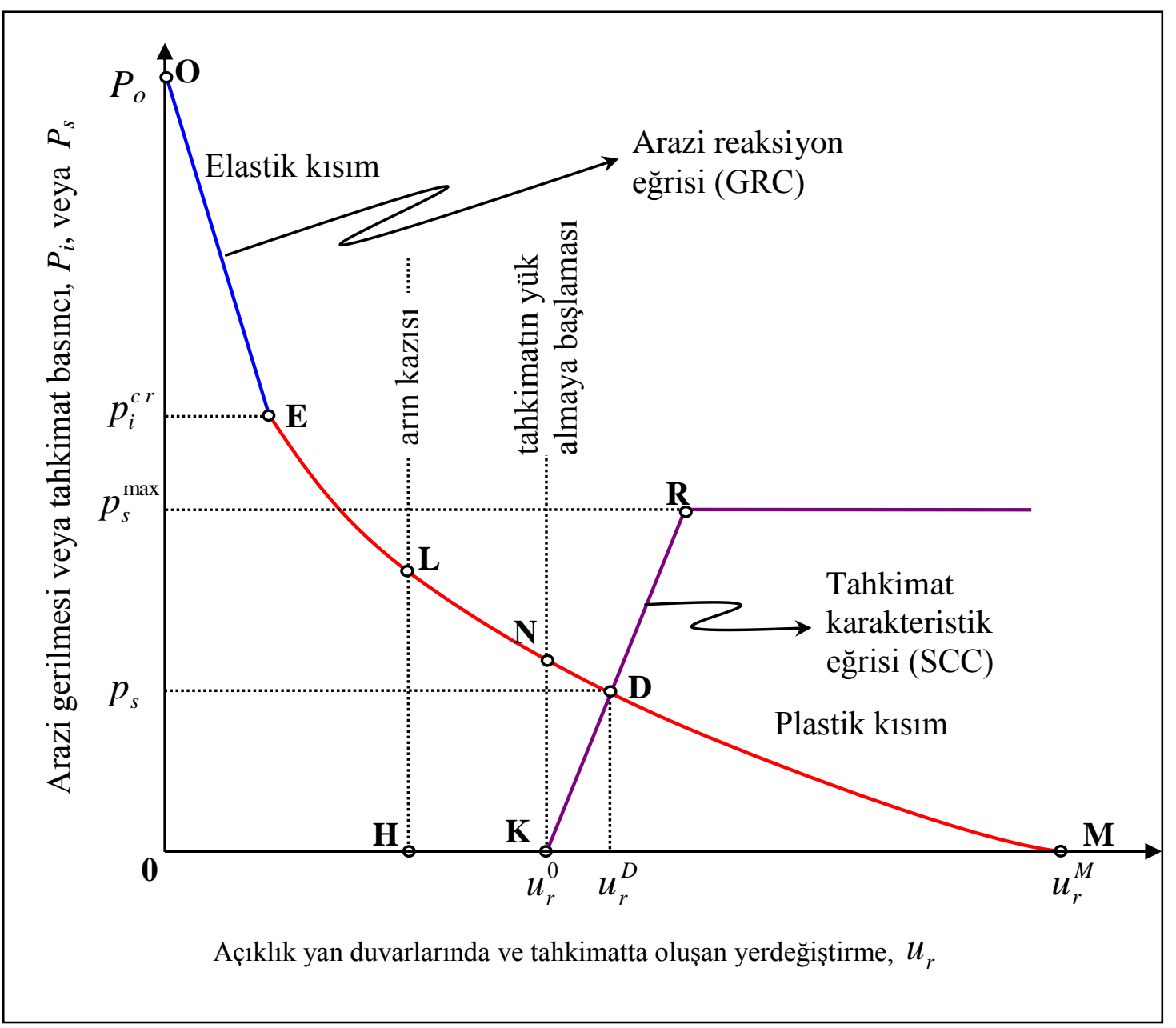

Şekil 1. Arazi tahkimat etkileşiminin şematik gösterimi ([2]'den değiştirilerek)

Burada, $\sigma_{\mathrm{ci}}$, kaya malzemesinin tek eksenli basınç dayanımı; $m_{b}$ ve $s$, H-B ölçütünde kaya kütlesinin özelliklerine bağlı sabitler ve $P_{i}^{c r}$, ölçeklendirilmiş kritik içsel basınç olup,

$P_{i}^{c r}=\frac{1}{16}\left[1-\sqrt{1+16 S_{o}}\right]^{2}$

burada, $S_{o}$, ölçeklendirilmiş birincil gerilme olup

$S_{o}=\frac{P_{o}}{m_{b} \sigma_{c i}}+\frac{s}{m_{b}^{2}}$ ile verilmektedir. Arazi reaksiyon eğrisinin elastik bölümünde (Şekil 1'de OE doğru parçası) $\left(p_{i} \geq p_{i}^{c r}\right)$

radyal yer değiştirme $\left(u_{r}^{e l}\right)$ ile içsel basınç arasındaki ilişki aşağıda verilmektedir:

$\boldsymbol{u}_{r}^{e l}=\frac{P_{o}-p_{i}}{2 G_{m}} R$

burada, $R$, açıklık kazı yarıçapı; $G_{m}$ ise kaya kütlesinin kesme (kayma) modülüdür.

İçsel basıncın kritik içsel basınçtan daha düşük olması durumunda $\left(p_{i}<p_{i}^{c r}\right)$ açıklık çevresinde 
yenilme bölgesi oluşmaktadır. Şekil 2'de gösterilen yenilme bölgesinin yarıçapı $\left(R_{p}\right)$ aşağıda verilen eşitlik ile bulunmaktadır [2]:
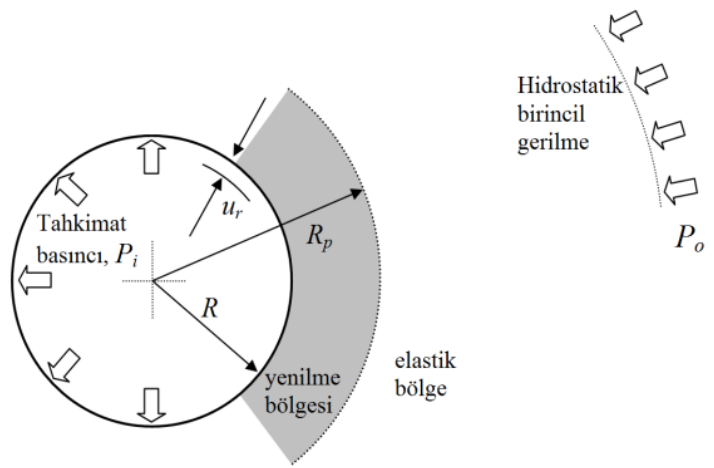

Şekil 2. Hidrostatik birincil gerilme alanında açıklık çevresinde oluşan yenilme bölgesi ve yer değiştirme ([2]'den değiştirilerek)

$$
R_{p}=R \exp \left[2\left(\sqrt{\mathrm{P}_{\mathrm{i}}^{\mathrm{cr}}-\sqrt{P_{i}}}\right)\right]
$$

Burada $P_{i}$, ölçeklendirilmiş içsel basınç olup,

$$
P_{i}=\frac{p_{i}}{m_{b} \sigma_{c i}}+\frac{s}{m_{b}^{2}}
$$

ile tanımlanmaktadır. Arazi reaksiyon eğrisinin plastik bölümünün (Şekil 1'de EM eğrisi) tanımlanması için malzemenin akış kuralı gereklidir. Akış kuralı, malzeme deformasyona uğrarken birim deformasyon ile hacimsel değişiklik arasındaki ilişki olarak tanımlanır. Yeraltı kazıları pratiğinde akış kuralı genellikle doğrusal olarak varsayılmakta olup hacimsel değişimin büyüklüğü dilatasyon açısı $(\psi)$ ile belirtilmektedir. Eğer $\psi=0^{\circ}$ ise malzeme plastik deformasyon boyunca hacimsel değişime uğramamakta, $\psi>0^{\circ}$ ise plastik deformasyon boyunca hacim artışına uğramaktadır.

Hoek ve Brown [3], kaya kütlesinin plastik hacimsel değişiminin olmadığı yaklaşımının çoğu durumlarda en uygun olabileceğini önermiştir. Dilatasyonun olmadığı $\left(\psi=0^{\circ}\right)$ kaya kütleleri için açıklık çevresinde oluşan plastik radyal yer değiştirme $\left(u_{r}^{p l}\right)$ ve arazi reaksiyon eğrisinin plastik bölümü (EM eğrisi) kolaylıkla hesaplanabilmektedir [2]:

$$
\begin{aligned}
\frac{u_{r}^{p l}}{R} \frac{2 G_{m}}{P_{o}-p_{i}^{c r}}= & {\left[\frac{1-2 v}{2} \frac{\sqrt{P_{i}^{c r}}}{S_{o}-P_{i}^{c r}}+1\right]\left(\frac{R_{p}}{R}\right)^{2}+\frac{1-2 v}{4\left(S_{o}-P_{i}^{c r}\right)}\left[\ln \left(\frac{R_{p}}{R}\right)\right]^{2} } \\
& -\frac{1-2 v}{2} \frac{\sqrt{P_{i}^{c r}}}{S_{o}-P_{i}^{c r}}+\left[2 \ln \left(\frac{R_{p}}{R}\right)+1\right]
\end{aligned}
$$

Tünel arını ve gerisinde oluşan radyal yer değiştirmenin açıklığın uzun ekseni boyunca değişimi ile ilgili birçok araştırmacı tarafından çalışmalar yapmıştır. Bu araştırmacılardan Panet [4], Ünlü ve Gerçek [5], Başarır ve arkadaşları [6] elastik çözümlemelere dayalı, Chern ve arkadaşları [7] de arazi ölçümlerine dayalı ve Hoek ve arkadaşları, [8] Aydan ve Geniş [9] elasto-plastik çözümlemelere dayalı eşitlikler önermiştir. Bu çalışmalardan, kazı yapıldığında tünel arınında oluşan yer değiştirmenin, açıklıkta oluşacak toplam yer değiştirmenin yaklaşık \%20-30'u civarında olduğu bulunmuştur. Tünel arınında kazı anında oluşan yer değiştirme Şekil 1'de "H" noktası olarak belirtilmiştir. Kuyu ekseninin tünel ekseninden farklı olarak düşey olduğu göz önünde bulundurulduğunda, kazı arınında oluşan radyal yer değiştirmenin kuyular için biraz farklı olabileceği unutulmamalıdır. $\mathrm{Bu}$ nedenle bu çalışmada fikir vermesi açısından kuyu arını civarında oluşan radyal yer değiştirmenin, kuyu arını gerisinde oluşan toplam yer değiştirmenin yaklaşık \%30’u olduğu varsayımı yapılmıştır.

\subsubsection{Tahkimat Karakteristik Eğrisinin (SCC) Oluşturulması}

Tahkimat karakteristik eğrisi (support characteristic curve, SCC) (Şekil 1) uygulanan tahkimat basıncı ile açıklık doğrultusundaki birim uzunluktaki tahkimatlı bölümünde oluşan radyal kapanma $\left(u_{r}\right)$ arasındaki ilişkiden bulunabilmektedir.

Tahkimat tarafından sağlanan basınç $\left(p_{s}\right)$ yani SCC'nin elastik bölümü (Şekil 1'de KR doğru 
parçası) tahkimatın elastik katılığı $\left(K_{s}\right)$ kullanılarak aşağıdaki eşitlikten bulunabilmektedir.

$$
p_{s}=K_{s} u_{r}
$$

Tahkimat katılığının $\left(K_{s}\right)$ birimi tahkimat basıncının birim uzunluğa bölümüdür $(\mathrm{MPa} / \mathrm{m})$.

Tahkimat karakteristiğinin plastik bölümü (Şekil 1'de R noktasından başlayan yatay doğru) tahkimatın yenilmeden önce taşıyabileceği en yüksek basınç ( $p_{s}^{\max }$ ) olarak tanımlanmaktadır. Değişik tahkimat türleri için en büyük tahkimat basıncı ve katılıklarını veren yaklaşımlar literatürde mevcuttur [9-11]. Bu çalışmada, kuyu tahkimatı beton olduğundan beton tahkimatla ilgili en yüksek tahkimat basıncı ve katılığı hakkında bilgi verilecektir.

Brady ve Brown [11]'a göre beton tahkimatın sağlayacağı en yüksek tahkimat basıncı;

$$
p_{s}^{\max }=\frac{\sigma_{c c}}{2}\left[1-\frac{\left(R-t_{c}\right)^{2}}{R^{2}}\right]
$$

eşitliği ile bulunabilir. Burada, $\sigma_{\mathrm{cc}}$, beton veya püskürtme betonun tek eksenli basınç dayanımı (MPa) ve $t_{c}$, beton kalınlığıdır (m). Kalınlığı $0.3 \mathrm{~m}$ olan 28 günlük ve $35 \mathrm{MPa}$ tek eksenli basınç dayanımına sahip beton tahkimatın sağlayabileceği en yüksek tahkimat (içsel) basıncı;

$$
p_{s}^{\max }=19.1(2 R)^{-0.92}
$$

ile hesaplanabilmektedir [12].

Beton tahkimatın elastik katılığı ise;

$$
K_{s}=\frac{E_{c}}{\left(1-v_{c}\right) R} \frac{R^{2}-\left(R-t_{c}\right)^{2}}{\left(1-2 v_{c}\right) R^{2}+\left(R-t_{c}\right)^{2}}
$$

ile verilmektedir. Burada, $E_{c}$, betonun deformasyon modülü $(\mathrm{MPa})$ ve $v_{c}$ ise betonun Poisson oranıdır [2,11].

\subsection{Sayısal Gerilme Çözümlemesi}

Sayısal gerilme çözümlemeleri için PHASE2 [13] bilgisayar programı kullanılmıştır. Söz konusu programın kullanımı kolay olduğu için mühendislik projelerinde oldukça yaygın bir kullanım alanına sahiptir. Program, sonlu elemanlar yöntemine dayalı zemin veya kayada ortamında yapılan yeraltı ve yerüstü yapıları için gerilme çözümlemeleri yapabilmektedir. Ayrıca program şev duraylığ 1 ve yeraltı suyu geçirimsizlik analizlerinde de kullanılmaktadır. Düzlem birim şekil değiştirme durumunun geçerli olduğu durumlarda iki boyutlu (tünel gibi) ve eksenel simetri durumuna sahip açıklıklar (büyük ölçekli yeraltı odaları gibi) için kısmen üç boyutlu gerilme çözümlemeleri hem statik hem de dinamik koşullar için yapılabilmektedir. Karmaşık ve çok aşamalı kazı ve tahkimat modellemeleri istenilen sayıda aşama ile oluşturulabilmekte ve kullanıcı dostu olması nedeniyle de oldukça hızlı modelleme ve sonuç alınabilmektedir.

Püskürme beton, beton, çeşitli tür kaya saplaması, çelik tahkimat ve bunların kombinasyonları gibi tahkimat seçeneği sağlayarak tasarımcıya projeye uygun tahkimat elemanları seçiminde ve tahkimatın duraylık için yeterliği konusunda hızlı bir öneri sağlayabilmektedir. PHASE2 programında kaya kütlesinin hem elastik hem de çeşitli yenilme ölçütleri kullanılarak elasto-plastik malzeme davranışları modellenebilmektedir. Elasto-plastik malzeme davranışları için Mohr-Coulomb, Hoek-Brown ve Drucker-Prager yenilme ölçütleri kullanılabilmektedir.

\section{3. ÇÖZÜMLEME GÍRDÍLERİ}

Kuyu arını ve gerisinde tahkimat kurulana kadar ve kurulduktan sonra oluşan yer değiştirmeler ve tahkimat yeterliği yapılan analitik ve sayısal gerilme çözümlemeleri ile belirlenerek karşılaştırılmıştır. Sayısal çözümlerde düzlem birim şekil değiştirme durumu göz önünde bulundurulmuştur. Öncelikle çözümlemelerde tanımlanan birincil gerilme durumları, kaya kütlesi özellikleri ve tahkimat özellikleri hakkında bilgiler verilecektir. 


\subsection{Açıklık Geometrisi ve Sınır Koşulları}

Kuyu için tipik olan dairesel kesitli açıklık geometrisi incelenmiştir. Açıklığın kazı çapı $9 \mathrm{~m}$ ve faydalı çap1 ise $8 \mathrm{~m}$ 'dir. Çözümlemelerde kullanılan sonlu elemanlar ağı Şekil 3'te verilmiştir. Kuyu geometrisi daire olduğu için açıklık geometrisi ile uygun olacak şekilde radyal şekilde ve model sınırına doğru genişleyen bir sonlu elemanlar ağı oluşturulmuştur. Sonlu elemanlar ağı 1260 dörtgen elemandan oluşmakta ve 12800 düğüm noktası içermektedir. Model sınırının açıklıktan uzaklığı, açıklık genişliğinin 10 katı olacak şekilde alınmıştır. Ayrıca, modelin dış sınırındaki tüm noktalar yatay ve düşey doğrultularda yer değiştirmeye izin vermeyecek şekilde sabitlenmiştir [14].

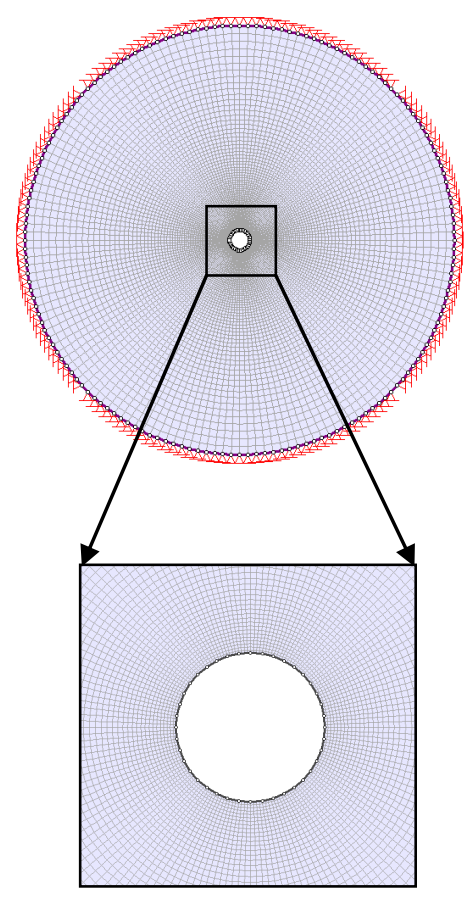

Şekil 3. Sayısal çözümlemelerde kullanılan sonlu elemanlar ağı ve sınır koşulları [14]

\subsection{Birincil Gerilme Durumu}

Çalışma sahasında herhangi bir birincil gerilme ölçümü bulunmamaktadır. İncelenen derinliklerdeki düşey birincil gerilmelerin örtü tabakası ağırlığı nedeniyle oluştuğu varsayımı yapılmıştır. Tüm kaya birimlerinin ortalama birim hacim ağırlığı $25 \mathrm{kN} / \mathrm{m}^{3}$ olarak alınmıştır. Ayrıca, yatay birincil gerilmelerin de düşey birincil gerilmeye eşit olduğu "hidrostatik birincil gerilme durumu" esas alınmıştır. Hidrostatik birincil gerilme durumu varsayımı, analitik çözümleme ile elde edilen sonuçların sayısal çözümleme ile elde edilen sonuçlarla karşılaştırılabilmesi olanağını sağlamıştır.

\subsection{Kaya Kütlesi Dayanım ve Deformasyon Özellikleri}

Kuyu boyunca farklı kaya birimlerini temsil edebilecek farklı derinliklerde analizlerin yapılmasına karar verilmiştir. Kaya kütlesinin elastik kusursuz plastik malzeme davranışı gösterdiği varsayılmıştır. Söz konusu kaya birimleri için analitik ve sayısal gerilme çözümlemelerinde kullanılan kaya malzemesi ve kütlesine ait dayanım ve deformasyon özellikleri Çizelge 1'de verilmiştir.

\subsection{Beton Tahkimat Özellikleri}

Tarlaağzı kuyusunda kuyu bileziği ve insetler dışında kuyu tahkimatı olarak C25 beton kullanılmıştır. Kuyu bileziği ve inset bölgelerinde ise C30 sınıfı beton kullanılmıştır. Sayısal çözümlemelerde, C25 betonun elasto-plastik malzeme davranışı gösterdiği varsayımı yapılmıştır. Betonun tek eksenli basınç dayanımı $25 \mathrm{MPa}$, çekme dayanımı 1,8 MPa, kalıcı tek eksenli basınç dayanımı $5 \mathrm{MPa}$, kalıcı çekme dayanımı 0, Young Modülü $30 \mathrm{GPa}$ ve Poisson oranı ise 0,2 olarak alınmıştır. Beton tahkimatın katılığ ${ }_{1}$ ise $838,8 \mathrm{MPa} / \mathrm{mm}$ olarak hesaplanmıştır [14].

\section{DURAYLIK DEĞERLENDIRMESİ}

Duraylılık çözümleri detayları bir önceki bölümde verilen "konverjans sınırlama" yöntemi ile kuyu kesitinin düzlem birim şekil değiştirme analizinin yapıldığı sonlu elemanlar yönteminin kullanıldığı sayısal gerilme çözümlemesi ile yapılmıştır. Çözümlemelerde yapılan varsayımlar iki 
Çizelge 1. Çözümlemelerde kullanılan kaya malzemesi ve kütlesinin özellikleri [14]

\begin{tabular}{|lcccccccccc|}
\hline Kaya Birimi & $\begin{array}{c}\text { Derinlik } \\
(\mathrm{m})\end{array}$ & $\begin{array}{c}\sigma_{\mathrm{ci}} \\
(\mathrm{MPa})\end{array}$ & $\mathrm{m}_{\mathrm{i}}$ & $\begin{array}{c}\mathrm{E}_{\mathrm{i}} \\
(\mathrm{GPa})\end{array}$ & $\mathrm{m}_{\mathrm{b}}$ & $\mathrm{s}$ & $\mathrm{GSI}$ & $\begin{array}{c}\sigma_{\mathrm{cm}} \\
(\mathrm{MPa})\end{array}$ & $\begin{array}{c}\mathrm{E}_{\mathrm{m}} \\
(\mathrm{GPa})\end{array}$ & $\begin{array}{c}\mathrm{P}_{\mathrm{o}} \\
(\mathrm{MPa})\end{array}$ \\
\hline Konglomera & $204-207$ & 35,8 & 8,80 & 12,5 & 3,60 & 0,0622 & 75 & 11,1 & 10,2 & 5,15 \\
Siltaş1 & $371-377$ & 18,3 & 5,67 & 6,9 & 0,95 & 0,0038 & 50 & 2,46 & 2,1 & 9,43 \\
İri taneli kumtaş1 & $629-634$ & 62,1 & 10,60 & 17,1 & 3,63 & 0,0357 & 70 & 17,8 & 12,5 & 15,85 \\
\hline
\end{tabular}

yöntemden alınan sonuçlarla karşıllaştırılmıştır. Sonuçta kuyu tahkimatı olarak uygulanan beton tahkimatın açıklığın duraylığını sağlama konusunda yeterliliği ortaya konmuştur.

Yeraltı kazılarında, kazı yapı1ır yapılmaz tahkimatın hemen kurulması ve anında yük almaya başlaması çoğu durumda çok zordur. Kazının çok kötü kaya koşulları içinde yapılması gereken bu durumlarda kazı yapılmadan önce kaya kütlesinin dayanım ve deformasyon özelliklerini iyileştirme yönünde bazı işlemler (örneğin enjeksiyon) gerekebilmektedir. Kazı arınında kazı işlemi yapıldığında, kaya kütlesi dayanım ve deformasyon özelliklerine bağlı olarak kaçınılmaz bir yer değiştirme oluşmaktadır. Eğer çevre kaya dayanım ve deformasyon özellikleri zayıf ise tahkimat kurulmadan önce oluşabilecek yer değiştirmeler de büyük olmaktadır. Tahkimatın kurulma zamanı ve uygun şekilde yük almaya başlaması, tahkimatın etkinliği ve açıklık duraylığı açısından büyük önem taşımaktadır. Tünel ekseni boyunca açiklık çevresinde oluşan radyal yer değiştirme dağılımlarının elastik ve elastoplastik çözümlemelerle incelendiği çalışmalarda [4-8,10], arından 0,25-4 tünel çapı uzaklıkta (genellikle kaya kütlesi koşullarına göre tahkimatın kurulmaya başladığı uzaklık) çevre kayada oluşacak toplam yer değiştirmelerin yaklaşık \%70-75'inin oluştuğu görülmektedir. $\mathrm{Bu}$ çalışmada, sayısal çözümlemelerde çevre kayada oluşacak yerdeğiştirmelerin $\% 65, \quad \% 70$ ve \%75'inin tahkimat kurulmaya başladığı anda oluştuğu varsayımı yapılmıştır.

$\mathrm{Bu}$ varsayım iki aşamalı yapılan tahkimatlı açıklık modellemesinde yük dağılımı (load split) ile tanımlanmıştır. Sayısal çözümlemelerde iki aşamalı yapılan tahkimatlı açıklık modellemesi yanında tek aşamalı tahkimatsız açıklık modellemesi de yapılmıştır. Farklı yük dağılımı koşullarında ( $\% 65, \% 70$ ve $\% 75)$ yapılan sayısal çözümlemelerden elde edilen sonuçlar analitik çözümlerle karşılaştırılarak en uygun yük dağılımı tespit edilmeye çalışılmıştır.

\subsection{Konglomera (204-207 m Seviyesi)}

Kuyunun 204-207 m derinliğinde orta dayanımlı konglomera birimi için çözümlemeler yapılmıştır. Öncelikle sayısal gerilme çözümlemeleri yapılmıştır. Tahkimatsız ve tahkimatlı durumda yapılan çözümlemelerde açıklık çevresinde herhangi bir yenilme bölgesi (plastik bölge) oluşmamaktadır. Diğer bir ifade ile kaya kütlesi elastik sınırlar içinde davranış sergilemiştir. Bu nedenle de açıklık yüzeyinde oluşan en büyük asal gerilme değeri en yüksek değerini almakta ve açıklıktan uzaklaştıkça birincil gerilme değerine yakınsamaktadır. En büyük asal gerilmeler tahkimatsız açıklıkta yaklaşı $10,3 \mathrm{MPa}$ ve tahkimatlı açıklıkta ise yaklaşık 9,7 MPa civarında oluşmaktadır (Şekil 4).

Hidrostatik birincil gerilme altında tahkimatsız dairesel açıklık çevresinde oluşan en büyük elastik gerilme, birincil gerilmenin iki katı olmaktadır.

Açıklık çevresinde oluşan yer değiştirme dağılımları tahkimatsız ve tahkimatlı açıklık durumlarında Şekil 5'te verilmiştir. Tahkimatsız açıklık çevresinde en büyük yerdeğiştirme $2,82 \mathrm{~mm}$ olarak belirlenmiştir (Şekil 5a). Tahkimatlı açıklığın modellendiği iki aşamalı analizde ise tahkimat kurulmadan önce açıklık çevresinde oluşan yer değiştirme $1,97 \mathrm{~mm}$ ve 
tahkimatla birlikte açıklığın son yer değiştirmesi $2,58 \mathrm{~mm}$ olarak elde edilmiştir (Şekil $5 \mathrm{~b}$ ve $5 \mathrm{c}$ ).

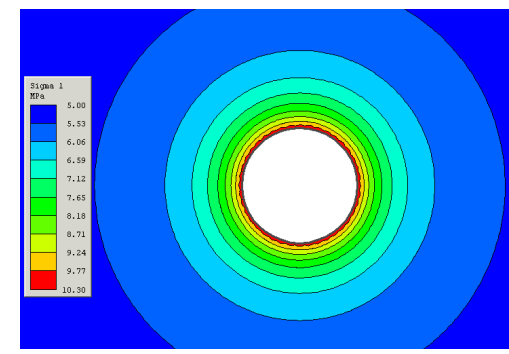

a. Tahkimatsız açıklık

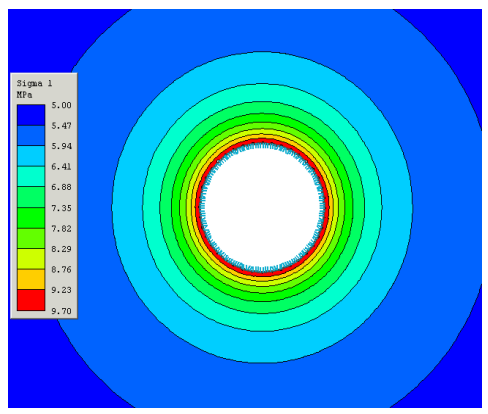

b. Tahkimatlı açıklık

Şekil 4. En büyük asal gerilme dağılımı (204-207 m seviyesi)

İki aşamalı sayısal çözümlemede yük dağılımlarının tahkimat kurulmadan önce $\% 70$, tahkimat kurulduktan sonra $\% 30$ olacağ belirlenmiştir. Söz konusu yük oranlarının belirlenmesi için farklı yük dağılımlarında çözümler gerçekleştirilmiştir. Farklı yük dağılımlarında yapılan aşamalı çözümlemelerde, tahkimat kurulmadan önce oluşan yerdeğiştirme ile tahkimat kurulduktan sonra oluşan yer değiştirme değerleri belirlenmiştir (Çizelge 2). Hem sayısal hem de analitik çözümleme ile elde edilen yer değiştirme değerleri karşılaştırılarak en uygun yük dağılımı değeri tespit edilmiştir (Çizelge 2).

Analitik çözümle elde edilen arazi reaksiyon eğrisi (GRC) ve tahkimat karakteristik eğrisi Şekil 6'da verilmiştir. Analitik ve sayısal gerilme çözümlemesi ile elde edilen yer değiştirme değerlerinin karşılaştırıldığında çok yakın sonuçların elde edildiği görülmektedir. Arazi reaksiyon eğrisi ile tahkimat eğrisinin kesiştiği noktada oluşan yer değiştirme tahkimatlı açıklıkta oluşan yer değiştirme olmaktadır.

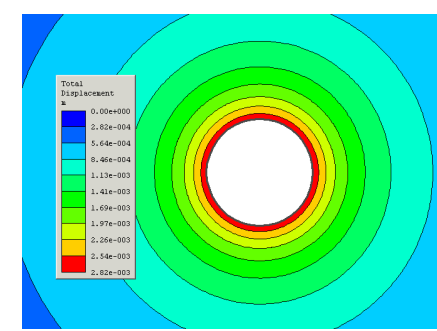

a. Tahkimatsız açıklık

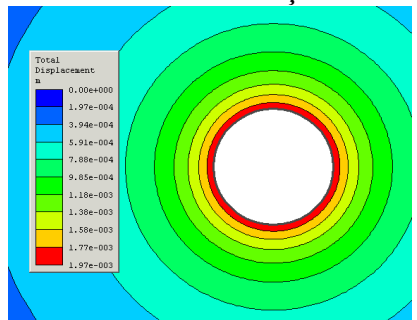

b. Tahkimat yapılmadan önce yer değiştirme

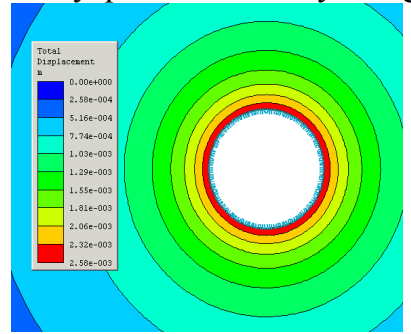

c. Tahkimat yapıldıktan sonraki yer değiştirme

Şekil 5. Tahkimatsız ve tahkimatlı açıklık çevresinde oluşan yer değiştirme dağılımları (204-207 m seviyesi)

Çizelge 2. Sayısal çözümleme ve analitik çözümleme sonuçları (204-207 m seviyesi)

\begin{tabular}{|c|c|c|c|c|c|}
\hline \multirow{2}{*}{$\begin{array}{l}\text { Yük } \\
\text { dağılımı } \\
\text { (1.aş - } \\
\text { 2.aş.) }\end{array}$} & \multirow{2}{*}{$\begin{array}{c}\text { 1. aşama } \\
\text { (tahkimat } \\
\text { kurulma- } \\
\text { dan önce) } \\
\begin{array}{c}U_{r} \\
(\mathrm{~mm})\end{array} \\
\end{array}$} & \multicolumn{2}{|c|}{$\begin{array}{c}\text { 2. aşama } \\
\text { (tahkimat } \\
\text { kurulduktan } \\
\text { sonra) }\end{array}$} & \multicolumn{2}{|c|}{$\begin{array}{l}\text { tahkimatsız } \\
\text { açıklık }\end{array}$} \\
\hline & & $\begin{array}{c}U_{r} \\
(\mathrm{~mm}) \\
\end{array}$ & $R_{p} / R$ & $\begin{array}{c}U_{r} \\
(\mathrm{~mm})\end{array}$ & $R_{p} / R$ \\
\hline$\% 65-\% 35$ & 1,83 & 2,54 & 0 & \multirow{3}{*}{$\begin{array}{c}2,82 \\
(2,85)\end{array}$} & \multirow{3}{*}{0} \\
\hline$\% 70-\% 30$ & $\begin{array}{c}1,97 \\
(1,95) \\
\end{array}$ & $\begin{array}{c}2,58 \\
(2,58) \\
\end{array}$ & 0 & & \\
\hline$\% 75-\% 25$ & 2,11 & 2,62 & 0 & & \\
\hline
\end{tabular}

Not: Parantez içindeki değerler analitik çözümle elde edilen sonuçlardır. 
Aynı noktanın düşey ekseni kesiștiği nokta ise tahkimat tarafından sağlanan tahkimat basıncı olup bu analizde yaklaşık $0,45 \mathrm{MPa}$ olduğu belirlenmiştir. Ayrıca çözümleme sonuçlarına göre de beton tahkimatta herhangi bir yenilme oluşmamıştır.

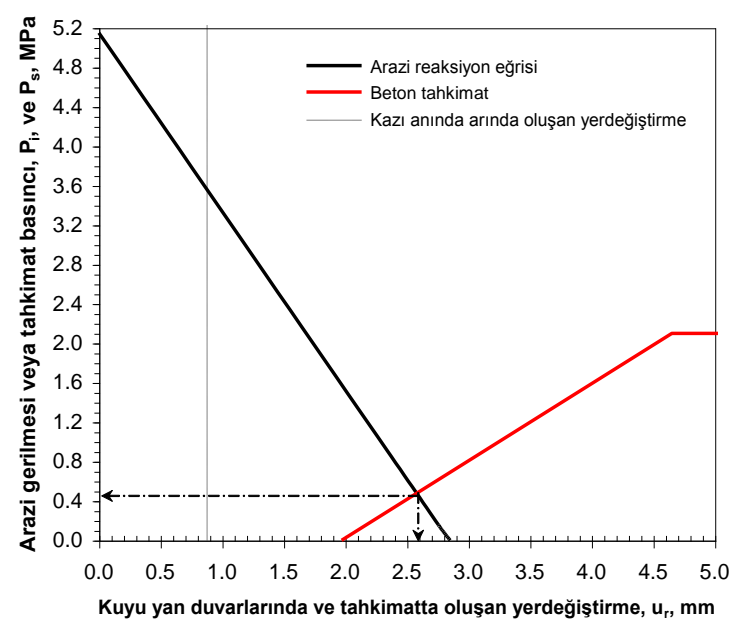

Şekil 6. Arazi reaksiyon eğrisi (GRC) ve tahkimat karakteristik eğrisi (204-207 m seviyesi)

\subsection{Silttaşı (371-377 m Seviyesi)}

Kuyunun 371-377 m derinliğinde düşük dayanımlı silttaşı birimi için çözümlemeler yapılmıştır. Öncelikle sayısal gerilme çözümlemeleri yapılmıştır. Tahkimatsız ve tahkimatlı durumda yapılan çözümlemelerde açıklık çevresinde yenilme bölgesi oluşmaktadır. $\mathrm{Bu}$ nedenle de açıklık çevresinde oluşan en büyük asal gerilme değeri en yüksek değerini elastik-plastik bölge sınırında almakta ve açıklıktan uzaklaştıkça birincil gerilme değerine yakınsamaktadır. En büyük asal gerilmeler tahkimatsız açıklıkta yaklaşık $14,3 \mathrm{MPa}$ ve tahkimatlı açıklıkta ise yaklaşık $12,8 \mathrm{MPa}$ civarında oluşmaktadır. Hidrostatik birincil gerilme ortamında dairesel açıklık çevresinde oluşan gerilme ve yer değiştirme dağılımları açıklık şekline uygun bir dağılım (dairesel) göstermektedir

Sayısal gerilme çözümlemesi ile tahkimatsız açıklık çevresinde en büyük yer değiştirme yaklaşık $97 \mathrm{~mm}$ olarak belirlenmiştir. Tahkimatlı açıklığın modellendiği iki aşamalı analizde ise tahkimat kurulmadan önce açıklık çevresinde oluşan yer değiştirme $53,8 \mathrm{~mm}$ ve tahkimatla birlikte açıklığın son yer değiştirmesi $56,0 \mathrm{~mm}$ olarak bulunmuştur. Analitik çözümleme ile tahkimatsız açıklıkta oluşacak en büyük yer değiştirme yaklaşı $105,2 \mathrm{~mm}$ olarak belirlenmiştir. Buna karşın tahkimat kurulmadan önce açıklık çevresinde oluşan yer değiştirme $55 \mathrm{~mm}$ ve tahkimatla birlikte açıklığın son yer değiştirmesi $56 \mathrm{~mm}$ olarak elde edilmiştir (Şekil 7).

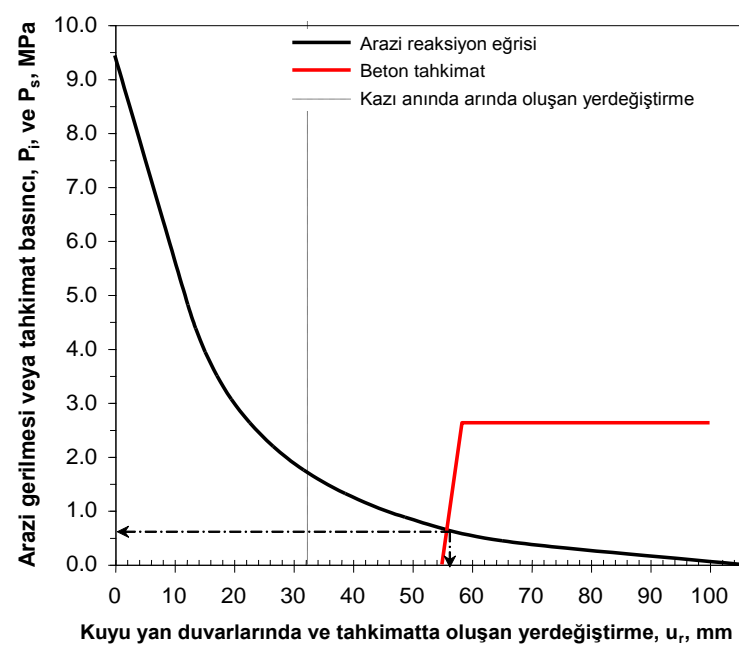

Şekil 7. Arazi reaksiyon eğrisi (GRC) ve tahkimat karakteristik eğrisi (371-377 m seviyesi)

Analitik ve sayısal gerilme çözümlemesi ile elde edilen tahkimatsız açıklık için yer değiştirme değerleri karşılaştırıldığında iki çözümlemeden birbirlerine yakın sonuçların elde edildiği görülmektedir (Çizelge 3). Arazi reaksiyon eğrisi ile tahkimat karakteristik eğrisinin kesiştiği noktada oluşan yer değiştirme değeri tahkimatlı açıklıkta oluşan yer değiştirme olmaktadır. Aynı noktanın düşey ekseni kesiştiği nokta ise tahkimat tarafindan sağlanan tahkimat basincı olup bu analizde yaklaşı $0,6 \mathrm{MPa}$ olduğu belirlenmiştir (Şekil 7 ve 9 b). Ayrıca çözümleme sonuçlarına göre de beton tahkimatta herhangi bir yenilme oluşmamaktadır. Sayısal çözümleme ile açıklık 
çevresinde oluşan yenilme bölgesi tahkimatsız açıklık ve tahkimatlı açıklık için Şekil 8'de verilmiştir. Açıklık çevresinde oluşan yenilme bölgesi hidrostatik birincil gerilme ortamı ve açıklık geometrisinin dairesel olması nedeniyle dairesel bir şekle sahip olmaktadır.

Çizelge 3. Sayısal çözümleme ve analitik çözümleme sonuçları $\quad(371-377 \mathrm{~m}$ seviyesi)

\begin{tabular}{|c|c|c|c|c|c|}
\hline \multirow{2}{*}{$\begin{array}{c}\text { Yük } \\
\text { dağılımı } \\
\text { (1.aş - } \\
\text { 2.aş.) }\end{array}$} & \multirow{2}{*}{$\begin{array}{c}\begin{array}{c}\text { 1. aşama } \\
\text { (tahkimat } \\
\text { kurulma- } \\
\text { dan önce) }\end{array} \\
\begin{array}{c}U_{r} \\
(\mathrm{~mm})\end{array}\end{array}$} & \multicolumn{2}{|c|}{$\begin{array}{l}\text { 2. aşama } \\
\text { (tahkimat } \\
\text { kurulduktan } \\
\text { sonra) }\end{array}$} & \multicolumn{2}{|c|}{$\begin{array}{l}\text { tahkimatsız } \\
\text { açılılık }\end{array}$} \\
\hline & & $\begin{array}{c}U_{r} \\
(\mathrm{~mm})\end{array}$ & $R_{p} / R$ & $U_{r}(\mathrm{~mm})$ & $R_{p} / R$ \\
\hline $\begin{array}{l}\% 65- \\
\% 35\end{array}$ & 41,83 & 45,29 & $\begin{array}{c}1,82 \\
(1,75)\end{array}$ & \multirow{3}{*}{$\begin{array}{c}96,99 \\
(105,18)\end{array}$} & \multirow{3}{*}{$\begin{array}{c}2,39 \\
(2,53)\end{array}$} \\
\hline $\begin{array}{c}\% 70- \\
\% 30\end{array}$ & 46,80 & 49,42 & $\begin{array}{c}1,89 \\
(1,82)\end{array}$ & & \\
\hline $\begin{array}{l}\% 75- \\
\% 25\end{array}$ & $\begin{array}{l}53,75 \\
(55,0)\end{array}$ & $\begin{array}{l}55,95 \\
(56,0)\end{array}$ & $\begin{array}{c}1,96 \\
(1,92)\end{array}$ & & \\
\hline
\end{tabular}

Not: Parantez içindeki değerler analitik çözümle elde edilen sonuçlardır.

Yenilme bölgesinin yarıçapının açıklığın yarıçapına oranı $\left(R_{p} / R\right)$, tahkimatsız açıklık için 2,39, tahkimatlı açıklık için de 1,96 olarak bulunmuştur. Analitik çözümlemelerde $R_{p} / R$, tahkimatsız açıklık için 2,53 ve tahkimatlı açıklık için de 1,92 olarak belirlenmiştir (Şekil 9).

Sayısal çözümlemelerde farklı yük dağılımlarında yapılan aşamalı çözümlemelerde, tahkimat kurulmadan önce oluşan yer değiştirme ile tahkimat kurulduktan sonra oluşan yer değiştirme değerleri belirlenmiştir Ayrıca tahkimat kurulduktan sonra oluşan yenilme bölgesi yarıçapının açıklığın yarıçapına oranları $\left(R_{p} / R\right)$ da elde edilmiştir (Çizelge 3). Hem sayısal hem de analitik çözümleme ile elde edilen yer değiştirme ve $R_{p} / R$ değerleri birbirleri ile karşılaştırılarak en uygun yük dağılımı değeri tespit edilmiştir.

İki aşamalı sayısal çözümlemede yük dağılımlarının incelenen bu durum için tahkimat kurulmadan önce $\% 75$, tahkimat kurulduktan sonra \%25 olacağı belirlenmiştir (Çizelge 3).

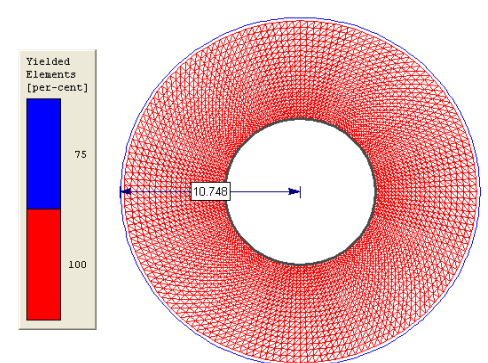

a. Tahkimatsız açıklık $\left(R_{p} / R=2,39\right)$

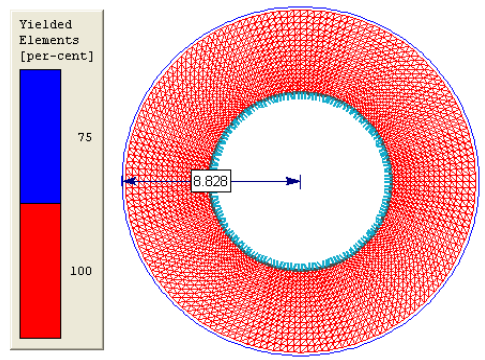

b. Tahkimatlı açıklık $\left(R_{p} / R=1,92\right)$

Şekil 8. Açıklık çevresinde oluşan yenilme bölgesi (371-377 m seviyesi)

\section{3. İri Taneli Kumtaşı (629-634 m Seviyesi)}

Kuyunun 629-634 m derinliğinde yüksek dayanımlı iri taneli kumtaşı birimi için çözümlemeler yapılmıştır. Öncelikle sayısal gerilme çözümlemeleri yapılmıştır. Tahkimatsız ve tahkimatlı durumda yapılan çözümlemelerde açıklık çevresinde yenilme bölgesi oluşmaktadır. Bu nedenle de açıklık çevresinde oluşan en büyük asal gerilme değeri en yüksek değerini elastikplastik bölge sınırında olmakta ve açıklıktan uzaklaştıkça birincil gerilme değerine yakınsamaktadır. En büyük asal gerilmeler tahkimatsız açıklıkta yaklaşık $28,7 \mathrm{MPa}$ ve tahkimatlı açıklıkta ise yaklaşı $28,5 \mathrm{MPa}$ civarında oluşmaktadır.

Tahkimatsız açıklık çevresinde en büyük yer değiştirme yaklaşık 8,24 mm olarak belirlenmiştir. Tahkimatlı açıklığın modellendiği iki aşamalı sayısal analizde ise tahkimat kurulmadan önce açıklık çevresinde oluşan yer değiştirme 5,31 mm ve tahkimatla birlikte açıklığın son yer değiştirmesi $6,92 \mathrm{~mm}$ olarak elde edilmiştir. 


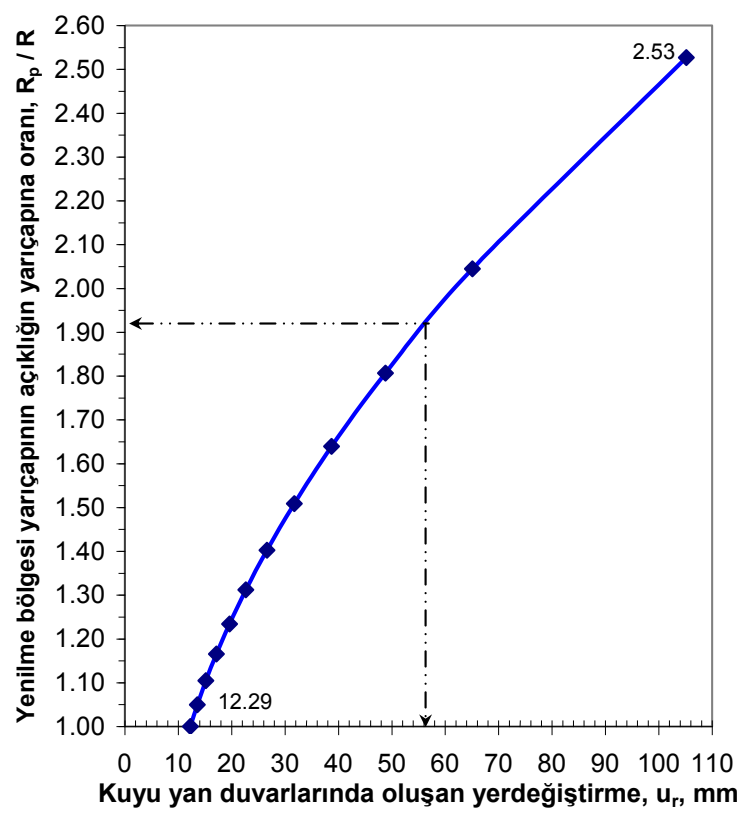

a. $R_{p} / R$ ve $u_{r}$

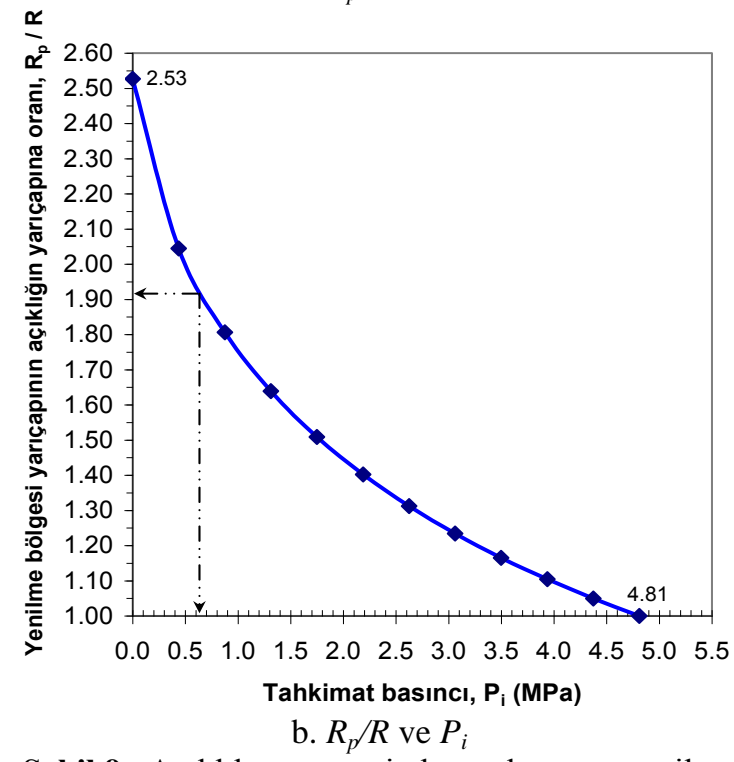

Şekil 9. Açıklık çevresinde oluşan yenilme bölgesinin açıklık çevresinde oluşan radyal yer değiştirme ve tahkimat basıncı ile değişimleri (371-377 m seviyesi)

Analitik çözümleme ile tahkimatsız açıklıkta oluşacak en büyük yer değiştirme yaklaşık $8,13 \mathrm{~mm}$ olarak belirlenmiştir. Buna karşın tahkimat kurulmadan önce açıklık çevresinde oluşan yerdeğiştirme $5,50 \mathrm{~mm}$ ve tahkimatla birlikte açıklığın son yerdeğiştirmesi $6,91 \mathrm{~mm}$ olarak elde edilmiştir (Şekil 10).

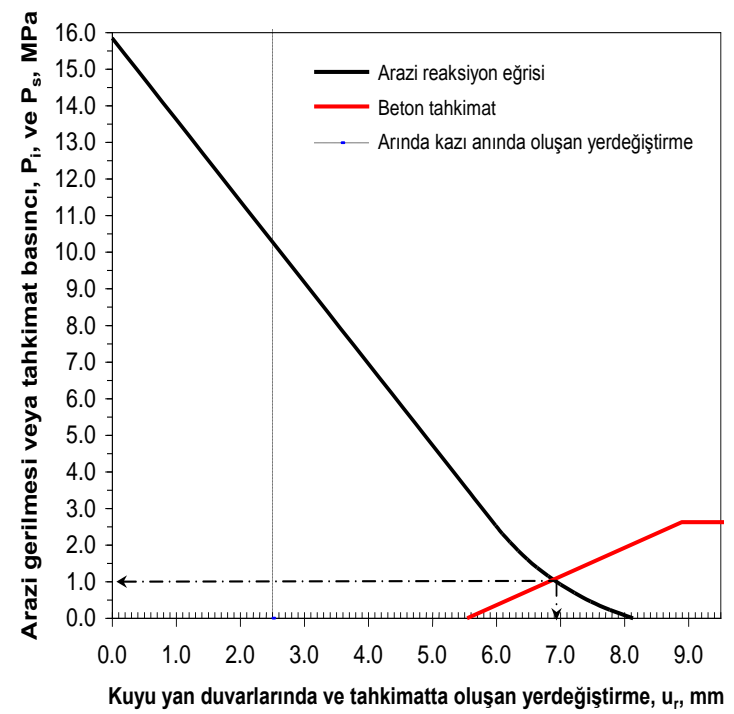

Şekil 10. Arazi reaksiyon eğrisi (GRC) ve tahkimat karakteristik eğrisi (629-634 m seviyesi)

Analitik çözümle elde edilen arazi reaksiyon eğrisi (GRC) ve tahkimat karakteristik eğrisi (SCC) Şekil 10'da verilmiştir. Analitik ve sayısal gerilme çözümlemesi ile elde edilen yer değiştirme değerlerinin karşılaştırıldığında yakın sonuçların elde edildiği görülmektedir (Çizelge 4). Arazi reaksiyon eğrisi ile tahkimat karakteristik eğrisinin kesiştiği noktada oluşan yer değiştirme değeri tahkimatlı açıklıkta oluşan yer değiştirme olmaktadır. Aynı noktanın düşey ekseni kesiştiği nokta ise tahkimat tarafindan sağlanan tahkimat basıncı olup bu analizde yaklaşık $1 \mathrm{MPa}$ olduğu belirlenmiştir (Şekil 10 ve 12.b). Ayrıca çözümleme sonuçlarına göre de beton tahkimatta herhangi bir yenilme oluşmamaktadır.

Sayısal çözümleme ile açıklık çevresinde oluşan yenilme bölgesi tahkimatsız açıklık ve tahkimatlı açıklık için Şekil 11'de verilmiştir. Yenilme bölgesinin yarıçapının açıklığın yarıçapına oranı $\left(R_{p} / R\right)$, tahkimatsız açıklık için 1,15 , tahkimatlı açıklık için de 1,061 olarak bulunmuştur. Analitik çözümlemelerde $R_{p} / R$, tahkimatsız açıklık için 1,14 
ve tahkimatlı açılık için 1,067 olarak belirlenmiştir (Şekil 12).

Çizelge 4. Sayısal çözümleme ve analitik çözümleme sonuçları (629-634 m seviyesi)

\begin{tabular}{|c|c|c|c|c|c|}
\hline $\begin{array}{c}\text { Yük } \\
\text { dağ1- } \\
\text { lımı }\end{array}$ & $\begin{array}{l}\text { 1. aşama } \\
\text { (tahkimat } \\
\text { kurulma- } \\
\text { dan önce) }\end{array}$ & $\begin{array}{r}2 . \\
\text { tal } \\
\text { kuru } \\
\text { s }\end{array}$ & $\begin{array}{l}\text { aşama } \\
\text { akimat } \\
\text { lduktan } \\
\text { onra) }\end{array}$ & & $\begin{array}{l}\text { natsiz } \\
\text { klik }\end{array}$ \\
\hline $\begin{array}{l}\text { (1.aş - } \\
\text { 2.aş.) }\end{array}$ & $\begin{array}{c}U_{r} \\
(\mathrm{~mm})\end{array}$ & $\begin{array}{c}U_{r} \\
(\mathrm{~mm})\end{array}$ & $R_{p} / R$ & $\begin{array}{c}U_{r} \\
(\mathrm{~mm})\end{array}$ & $R_{p} / R$ \\
\hline $\begin{array}{c}\% 65 \\
\% 35\end{array}$ & 4,84 & 6,71 & $\begin{array}{c}1,080 \\
(1,055)\end{array}$ & \multirow{3}{*}{$\begin{array}{c}8,24 \\
(8,13)\end{array}$} & \multirow{3}{*}{$\begin{array}{c}1,15 \\
(1,14)\end{array}$} \\
\hline $\begin{array}{c}\% 70 \\
- \\
\% 30\end{array}$ & $\begin{array}{c}5,31 \\
(5,50)\end{array}$ & $\begin{array}{l}6,92 \\
(6,91)\end{array}$ & $\begin{array}{c}1,061 \\
(1,067)\end{array}$ & & \\
\hline $\begin{array}{c}\% 75 \\
- \\
\% 25\end{array}$ & 5,73 & 7,06 & $\begin{array}{c}1,061 \\
(1,077)\end{array}$ & & \\
\hline
\end{tabular}

Not: Parantez içindeki değerler analitik çözümle elde edilen sonuçlardır.

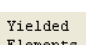

Yielded
Elements
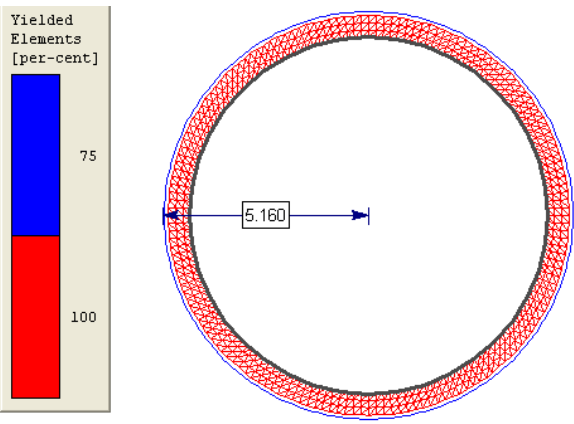

a. Tahkimatsız açıklık $\left(R_{p} / R=1,15\right)$
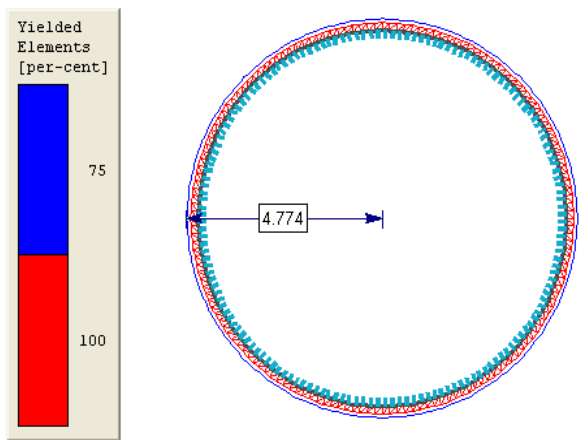

b. Tahkimatlı açıklık $\left(R_{p} / R=1,061\right)$

Şekil 11. Açıklık çevresinde oluşan yenilme bölgesi (629-634 m seviyesi)

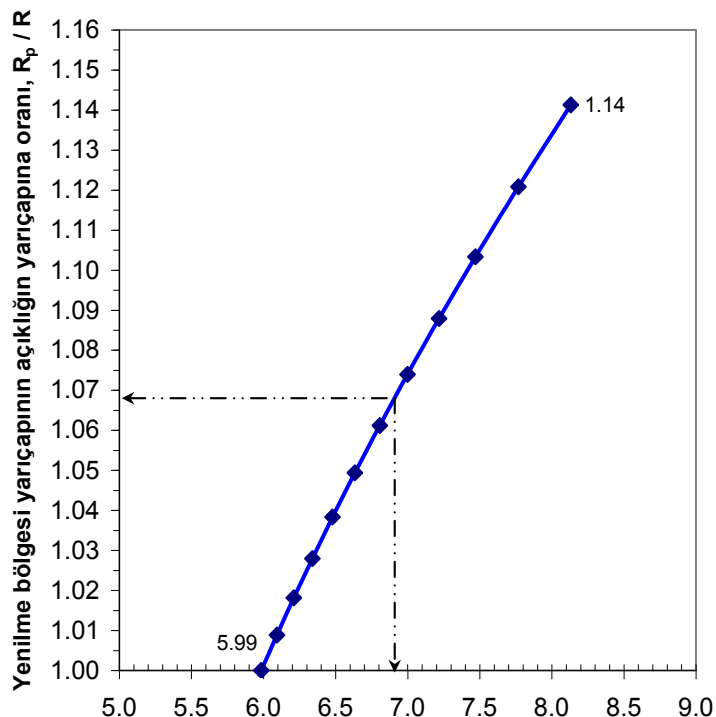

Kuyu yan duvarlarında oluşan yerdeğiştirme, $u_{r}, \mathrm{~mm}$ a. $R_{p} / R$ ve $u_{r}$

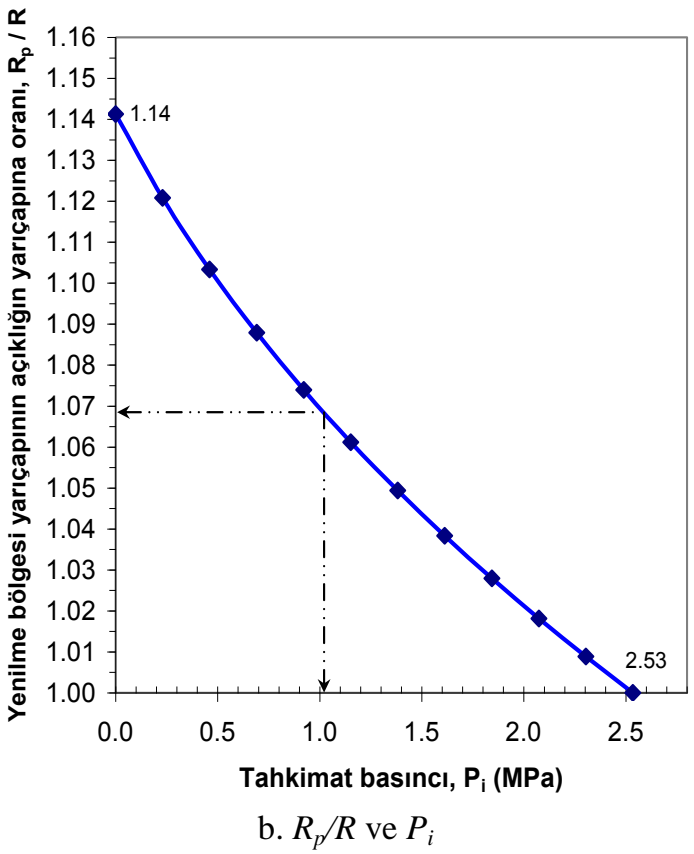

Şekil 12. Açıklık çevresinde oluşan yenilme bölgesinin açıklık çevresinde oluşan radyal yer değiştirme ve tahkimat basıncı ile değişimleri (629-634 m seviyesi) 


\section{GENEL DEĞERLENDİME}

Kuyu derinliği boyunca karşılaşılan tipik kaya birimlerinden konglomera, silttaşı ve iri taneli kumtaşı birimleri için farklı derinliklerde düzlem birim deformasyon analizleri yapılmıştır. Özellikle belirli derinlik seviyelerinde, kendi içlerinde genellikle en düşük dayanım ve deformasyon modülü özelliklerine sahip olan birimler analizlerde göz önünde bulundurulmuştur.

Sonlu elemanlar çözümleme yönteminin kullanıldığı ve tahkimat modellemesi yapılan analizlerde en önemli konu tahkimat kurulmadan önce ve kurulduktan sonra yük dağılım oranlarının belirlenmesidir. $\mathrm{Bu}$ konu doğrudan tahkimatın kurulma zamanı ile ilişkilendirilmektedir. Kazı yapılır yapılmaz tahkimatın kurulduğu durumlarda (katı tahkimat) arazide oluşacak yer değiştirmelere çok fazla izin vermeyecektir. Bazı durumlarda tahkimatın çok erken kurulması tahkimatın kapasitesini aşan yüklere maruz kalmasını sağlayacak ve tahkimat elemanı yenilecektir. Bununla birlikte kazı yapıldı ̆̆ı anda kaçınılmaz oluşan yer değiştirmelere ilave olarak tahkimatın kurulması için geçen sürede de arazi ile birlikte tahkimat yer değiştirecektir. Çok geç kurulan tahkimatlarda kaya kütlesinin elasto-plastik deformasyonu çok fazla oluşacak ve tahkimat yeterli yük almadığı için işlevini yapamayacaktır. Sayısal çözümlemede kullanılan iki aşamalı tahkimat modellemesi yapılan çözümlerde "yük dağılımı" işlevi kullanılarak yukarıda açıklanan durum modellenmiştir. $\mathrm{Bu}$ yük dağılımı tahkimat kurulana kadar olan birinci aşama için \%70-75 ve tahkimat kurulduktan sonraki aşama için de \%25-30 arasında değiştiği tespit edilmiştir. $\mathrm{Bu}$ durum 'Konverjans Sinırlama Yöntemi' kullanılarak yapılan analitik çözümlemelerle de sınanmıştır.

\section{SONUÇLAR}

Bu çalışmada, özel sektör tarafindan AmasraBartın'da açılan Tarlaağzı üretim kuyusunun inset bölgeleri dışındaki bölümlerinde duraylılık incelemeleri yapılmıştır. Kuyunun duraylılık çözümleri hem sayısal gerilme hem de analitik çözümleme yöntemi ile yapılmıştır. Genellikle orta ve yüksek dayanımlı kaya birimlerinde açılan kuyuda herhangi bir duraysızlık probleminin bulunmadığı ortaya konulmuştur. Bu bulgular saha gözlemler ile uyumludur. Bu çalışma ile ilgili elde edilen genel sonuçlar aşağıda sıralanmıştır:

- Kuyunun $300 \mathrm{~m}$ derinliğe kadar yapılan tüm analizlerde açıklık çevresinde herhangi bir yenilme bölgesi oluşmamıştır. Kaya kütlesi elastik davranış göstermiştir. $300 \mathrm{~m}$ den daha derinlerde ise açıklık çevresinde yenilme bölgesi oluşmaktadır. Kuyunun 371-377 m derinliğinde bulunan silttaşı biriminde yapılan çözümlemelerde en büyük yenilme bölgesi oluşmaktadır. Yenilme bölgesinin yarıçapının açıklık yarıçapına oranı yaklaşık 2,4 civarında oluşmuştur. Hidrostatik birincil gerilme alanı varsayımında yapılan çözümlemelerde yenilme bölgesi şekli açıklık kesit şekli ile aynı olup daireseldir. Ayrıca en büyük yerdeğiştirme de siltaşı biriminde oluşmuştur.

- Sayısal çözümlemelerde, kuyunun inset bölgeleri dışında uygulanan $50 \mathrm{~cm}$ kalınlığında C25 betonda incelenen durumlarda herhangi bir yenilme olgusu yapilan analizlerde bulunmamıştır. Sonuç olarak bütün kaya birimler için kullanılan aynı özellikteki C25 betonun kuyu tahkimatı için yeterli olduğu bulunmuştur.

- Tahkimat tarafından sağlanan basınçlar $\left(p_{s}\right)$, analitik ve sayısal çözümlemelerin sonuçlarından faydalanılarak elde edilmiştir. Kuyu derinliği arttıkça tahkimat basınçları da beklendiği gibi artış göstermektedir. İncelenen durumlar için $200 \mathrm{~m}$ derinliklerde tahkimat basinc1 $0,45 \mathrm{MPa}$ ve en derinde $(630 \mathrm{~m})$ ise yaklaşık 1,0 MPa olarak bulunmuştur.

- İki aşamalı tahkimat modellemesi yapılan sayısal çözümlerde "yük dağılımı" işlevi kullanılmıştır. $\mathrm{Bu}$ işlev ile tahkimat kurulana kadar geçen sürede birincil gerilmelerin kaya kütlesinde oluşturacağı şekil değiştirmesinin ne 
kadarlık bölümünün etkin olduğu oransal olarak girilmektedir. Gerçekte arazide bu oranın sağlıklı bir şekilde ölçümü oldukça zor ve zahmetlidir. Sayısal çözümlemelerde yük dağılım oranları tahkimat kurulana kadar olan birinci aşama için $\% 65, \% 70, \% 75$ ve tahkimat kurulduktan sonraki aşama için de \%35, \%30, \%25 olacak şekilde seçilmiştir. Bu farklı yük dağılımları durumunda oluşan yer değiştirmeler ve yenilme bölgesi büyüklükleri konverjans sınırlama yöntemi kullanılarak yapılan analitik çözümlemelerle de sınanmıştır. Sonuçta, yük dağılımı oranlarının tahkimat kurulana kadar olan birinci aşama için \%70-75 ve tahkimat kurulduktan sonraki aşama için de \%25-30 arasında değiştiği tespit edilmiştir.

- Yeraltı açıklıklarının kazı ve tahkimat modellemesinin yapıldığı iki ve üç boyutlu sayısal çözümlemelerde, kullanıcı tarafindan mutlaka 'yük dağılımı' işlevinin kullanılması gerekmektedir. $\mathrm{Bu}$ işlev kazının yapılması ve tahkimatın kurulması arasında arazinin deformasyonuna tanımlanan oranlarda izin vermektedir. Genellikle kullanıcı tarafindan kurulan modelde bazen hatalar yapılabilmektedir. Şöyle ki, genellikle kazı aşamasından sonra tahkimatın modellendiği 2 . aşamada 'yük dağılımı (load split)' uygulanmadığında (ya da kullanıcı tarafından yanlış oranlar seçildiğinde) tahkimat elemanı 2. aşamada sayısal olarak herhangi bir yük almayacaktır. Sonuçta yük almayan tahkimat elemanında ikincil gerilmeler ne kadar yüksek olursa olsun herhangi bir yapisal yenilme oluşmayacaktır. $\mathrm{Bu}$ durum bazen kullanıcı tarafından tahkimat elemanının yenilmediği yani tahkimatın yeterli olduğu şeklinde yanlış yorumlanabilecektir.

- Kazı ile tahkimat elemanının tek aşamalı olarak aynı anda (yani kazının yapılır yapılmaz tahkimatın uygulandığ çözümlemelerde tahkimat elemanına aniden ortamdaki birincil gerilme etkiyecektir. $\mathrm{Bu}$ durum genellikle yüksek birincil gerilme değerlerinde, elasto-plastik malzeme davranış1 varsayımı yapılan tahkimat elemanın yenilmesi ile sonuçlanacaktır. Modellenen bu durum, arazi-tahkimat etkileşiminde göz önünde bulundurulan bir noktadaki deformasyonların kazı arını o noktaya yaklaşmadan başladığı gerçeğine aykırıdır. Sayısal çözümlemeler kullanan tasarım mühendislerinin burada anlatılan hususları göz önünde bulundurmaları, elde edilecek sonuçların güvenirliği açısından büyük önem taşımaktadır.

\section{TEŞEKKÜR}

Yazarlar, çalışmanın yürütülmesinde yardımlarından dolayı Merhum Maden-Jeoloji Mühendisi Avni Akyüz (HEMA)'e, Maden Mühendisi Suat Ölmez (HEMA)'e, Maden Y. Mühendisi Eren Soyer (HEMA)'e teşekkürü borç bilirler.

\section{KAYNAKLAR}

1. Geniş, M., Gerçek, H., 2000. Yeraltı açıklıklarının dinamik tasarımı. V. Ulusal Kaya Mekaniği Sempozyumu Bildiriler Kitabı, S. Saraç vd. (ed.), Türk Ulusal Kaya Mekaniği Derneği, Ankara, 65-72.

2. Carranza-Torres C., Fairhurst, C., 2000. Application of the Convergence-Confinement Method of Tunnel Design to Rock Masses that Satisfy the Hoek-Brown Failure Criterion. Tunnelling and Underground Space Technology, 15 (2), 187-213.

3. Hoek, E., Brown, E.T., 1997. Practical Estimates of Rock Mass Strength. Int. J. Rock Mech. Min. Sci., 34, 1165-1186.

4. Panet, M., 1995. Calcul des Tunnels par la Me'thode de Convergence-Confinement. Presses de l'Ecole Nationale des Ponts et Chaussẻes, Paris, 178 p.

5. Ünlü, T., Gerçek, H., 2003. Effect of Poisson's Ratio on the Normalized Radial Displacements Occurring Around the Face of A Circular Tunnel. Tunnelling and Underground Space Technology, 18, 547-553. 
6. Başarır, H., Geniş, M., Özarslan, A., 2010. The Analysis of Radial Displacements Occurring Near The Face of a Circular Opening in Weak Rock Mass. Int. Journal of Rock Mechanics and Mining Sciences, Elsevier, 47 (5), 771-783.

7. Chern, J.C., Shiao, F.Y., Yu, C.W., 1998. An Empirical Safety Criterion for Tunnel Construction". Proceedings of the Regional Symposium on Sedimentary Rock Engineering, Taipei, Taiwan, 222-227.

8. Hoek, E., Carranza-Torres, C., Diederichs, M.S., Corkum, B., 2008. Integration of Geotechnical and Structural Design in Tunnelling. Proceedings University of Minnesota 56th Annual Geotechnical Engineering Conference, Minneapolis, 1-53.

9. Aydan, Ö., Geniş, M., 2010. A Unified Analytical Solution for Stress and Strain Fields about Radially Symmetric Openings in Elasto-Plastic Rock with the Consideration of Support System and Long-Term Properties of Surrounding Rock". International Journal of Mining and Mineral Processing, International Science Press, 1 (1), 1-32.

10. Hoek, E., Brown, E.T., 1980. Underground Excavations in Rock. Institution of Mining and Metallurgy, Stephen Austin and Sons, London, $527 \mathrm{p}$.

11. Brady, B.H.G., Brown, E.T., 1985. Rock Mechanics for Underground Mining. Chapman and Hall, London, 557 p.

12. Hoek, E., 1998. Tunnel support in weak rock. Symposium of Sedimentary Rock Engineering, Taipei, Taiwan, 12 p.

13. Rocscience, 2007. Phase 2 , Toronto, Canada, http://www.rocscience.com/

14. Acun, D., 2009. Amasra Tarlaağzı Kuyusu Çevre Kaya Özellikleri ve Duraylılığının İncelenmesi. Yük. Müh. Tezi, Zonguldak Karael-mas Üniv. Fen Bil. Enst. Maden Mühendisliği Anabilim Dalı, Zonguldak, 157 s. 
